\title{
PENGHAMBATAN AKTIVITAS XANTHINE OXIDASE OLEH EKSTRAK ETANOL SARANG SEMUT (Myrmecodia tuberosa (non Jack) Bl.) SECARA IN VITRO
}

\section{IN VITRO XANTHINE OXIDASE INHIBITION ACTIVITY OF THE SARANG SEMUT (Myrmecodia tuberosa (non Jack) Bl.) ETHANOL EXTRACT}

\author{
Ernawati, Hari Susanti \\ Fakultas Farmasi Universitas Ahmad Dahlan \\ Jl. Prof. Dr. Soepomo SH, Yogyakarta, Telp. (0274) 379418 \\ Email:susan_uadjogja@yahoo.com
}

\begin{abstract}
ABSTRAK
Asam urat merupakan produk akhir metabolisme purin mengendap di persendian dan membentuk kristal kecil sehingga menimbulkan peradangan yang dikenal dengan gout. Gout merupakan penyakit metabolik yang terjadi akibat tingginya kadar asam urat dalam darah (hiperurisemia). Salah satu obat yang digunakan untuk mengatasi gout adalah allopurinol dengan mekanisme menghambat aktivitas xanthine oxidase. Tumbuhan sarang semut diketahui mengandung flavonoid dan terbukti secara empiris untuk mengobati keluhan rematik dan asam urat. Oleh karena itu, perlu dilakukan penelitian untuk menguji apakah ekstrak etanol sarang semut mampu menghambat aktivitas xanthine oxidase. Ekstrak etanol sarang semut dibuat dengan menggunakan metode maserasi. Sebelum penyarian dilakukan pengawalemakan menggunakan petroleum eter (PE). Penghambatan aktivitas xanthine oxidase oleh ekstrak etanol sarang semut secara in vitro ditentukan melalui penurunan produksi asam urat yang dimonitor dengan spektrofotometer pada $(\lambda) 295 \mathrm{~nm}$ dengan xanthine sebagai substrat. Nilai rate yang diperoleh selanjutnya digunakan untuk menghitung nilai aktivitas. Kemudian ditentukan $\mathrm{IC}_{50}$. Sebagai pembanding digunakan allopurinol. Hasil penelitian menunjukkan bahwa ekstrak etanol sarang semut mampu menghambat aktivitas xanthine oxidase dengan $\mathrm{IC}_{50} 112,40 \mu \mathrm{g} / \mathrm{ml}$ lebih lemah dibandingkan $\mathrm{IC}_{50}$ allopurinol sebesar 3,16 $\mu \mathrm{g} / \mathrm{ml}$.
\end{abstract}

Kata kunci : asam urat, hiperurisemia, Xanthine Oxidase, sarang semut

\begin{abstract}
Uric acid is the end product of purine metabolism that can settle in the joints and form small crystals, causing inflammation known as gout. Gout is a disease caused by high levels of uric acid in the blood (hyperuricemia). One of the drugs used to treat gout was allopurinol to inhibite the activity of xanthine oxidase mechanism. Myrmecodia tuberosa (non Jack) Bl. known to contain flavonoids and empirically proven to treat rheumatic complaints and gout. Therefore, research needs to examine whether the ethanol extract of the sarang semut to inhibite xanthine oxidase activity. Allopurinol is used as a comparison. The active substances of the Myrmecodia tuberosa (non Jack) Bl. was extracted with ethanol using maceration method after soaked with petroleum ether. The xanthine oxidase inhibitor activity of the Myrmecodia tuberosa (non Jack) Bl production ethanol extract was spectrophotometrically determined by monitoring the reducing of uric acid at a wavelength ( $\lambda$ ) $295 \mathrm{~nm}$ with xanthine as substrate. Rate values obtained subsequently used to calculate the value of the activity. Then determined the concentration of the ethanol extract can inhibit the activity of xanthine oxidase by $50 \%\left(\mathrm{IC}_{50}\right)$. The results of the research showed that the ethanol extracts of
\end{abstract}


sarang semut inhibited xanthine oxidase activity with $\mathrm{IC}_{50} 112.40 \mu \mathrm{g} / \mathrm{ml}$, while allopurinol was $3.16 \mu \mathrm{g} / \mathrm{ml}$.

Keywords: Uric acid, Hyperuricemia, Xanthine Oxidase, Myrmecodia tuberosa (non Jack) Bl

\section{PENDAHULUAN}

Asam urat adalah produk dari metabolisme purin yang mengendap di persendian dan membentuk kristal kecil sehingga menimbulkan rasa nyeri yang hebat dan kaku, juga pembesaran dan penonjolan sendi yang bengkak. Pada kondisi tertentu dapat terjadi peningkatan kadar asam urat dalam darah melebihi batas normal yang disebut hiperurisemia (Walker dan Edward, 2003). Hiperurisemia dapat disebabkan oleh tingkat produksi asam urat yang berlebih, ekskresi asam urat melalui ginjal yang berkurang atau kombinasi keduanya (Wibowo, 2006). Hiperurisemia yang lanjut dapat berkembang menjadi gout. Gout merupakan jenis penyakit metabolik yang keberadaannya cukup populer dikalangan masyarakat dengan sebutan pirai (Price dan Wilson, 2005).

Obat sintetik yang biasa digunakan untuk mengatasi asam urat adalah allopurinol. Allopurinol merupakan suatu analog asam urat, bekerja menghambat pembentukan asam urat dari prekursornya (xanthine dan hipoxanthine) dengan menghambat aktivitas enzim xanthine oksidase (Price dan Wilson, 2005). Akan tetapi allopurinol memiliki beberapa efek samping yaitu kemerahan pada kulit, leukopenia, kadang-kadang terjadi toksisitas pada gastrointestinal dan meningkatkan serangan akut gout pada awal terapi (Dipiro dkk., 2005). Oleh karena itu, sekarang masyarakat banyak yang menggunakan tanaman obat sebagai obat tradisional karena memiliki efek samping yang relatif kecil, mudah didapatkan, dan harganya relatif murah dibandingkan dengan obat sintesis.

Salah satu tanaman obat yang saat ini mulai banyak diteliti adalah sarang semut. Tanaman ini secara empiris digunakan oleh masyarakat asli Wamena untuk mengobati keluhan rematik dan asam urat. Menurut penelitian para ahli Bioteknologi LIPI, zat utama yang dimiliki sarang semut adalah flavonoid dan tanin (Subroto dan Hendro, 2006). Dan dari hasil Isolasi senyawa aktif dari ekstrak hipokotil sarang semut (Myrmecodia pendens Merr. \& Perry) sebagai penghambat enzim xanthine oxidase menunjukkan bahwa fraksi n-butanol mampu menghambat enzim xanthine oxidase sebesar 61,99\% dan setelah dilakukan pemurnian menjadi isolat murni meningkat menjadi 79,77\% (Subroto dkk., 2010). Penelitian Cos dkk., (1998) menyebutkan bahwa beberapa senyawa flavonoid mampu menghambat aktivitas xanthine oxidase sehingga dapat menurunkan kadar asam urat dalam darah.

Berkaitan dengan keberadaan flavonoid dan kemampuan dalam menghambat aktivitas enzim xanthine oxidase, maka perlu dilakukan penelitian untuk menguji apakah ekstrak etanol sarang semut mampu menghambat aktivitas enzim xanthine oxidase.

\section{METODE PENELITIAN}

\section{Alat}

Spektrofotometer Shimadzu Pharmaspec UV 1700, alat untuk maserasi, $\mathrm{pH}$ meter ORION, rotary evaporator, neraca analitik (Sartorius), mikropipet (Soccorec), ultrasonic, millipore, dan alat-alat gelas yang lazim.

\section{Bahan}

Bahan utama yang digunakan adalah umbi tanaman sarang yang diperoleh dari Papua pada bulan April 2012. Bahan kimia meliputi: allopurinol, xanthine oxidase (mikrobial) diperoleh dari Sigma Aldrich, xanthine diperoleh dari sigma Chemical Co, petroleum eter (kualitas teknis) dari PT. Brataco, etanol 96\% diperoleh dari CV. Multi Kimia, dimetilsulfoksida (DMSO), n-butanol, asam asetat glasial, kalium dihidrogen fosfat, natrium hidroksida kualitas pa diperoleh dari E. Merck, Aquadestilata diperoleh dari CV. Multi Kimia. 


\section{Jalannya Penelitian}

\section{Identifikasi tanaman}

Tanaman sarang semut dideterminasi di Bagian Biologi Farmasi Fakultas Farmasi UGM Yogyakarta.

\section{Penyiapan bahan uji \\ a. Pembuatan serbuk}

Tanaman sarang semut dibersihkan dari kotoran, dipotong-potong, setelah itu dikeringkan di oven pada suhu $55^{\circ} \mathrm{C}$. Pengeringan dihentikan jika sudah mudah dipatahkan dan kadar air $7,296 \%<10 \%$. Sarang semut yang sudah kering dijadikan serbuk.

\section{b. Pembuatan ekstrak}

Ekstrak etanol sarang semut dibuat dengan cara maserasi. Sebelum proses maserasi, terlebih dahulu dilakukan pengawalemakan dengan cara merendam serbuk sarang semut dengan petroleum eter untuk menghilangkan lipid agar tidak mengganggu proses penyarian. Setelah itu, sebanyak 100 gram serbuk sarang semut yang telah ditimbang direndam dengan etanol 96\% diaduk dengan magnetik stirrer selama 2 jam didiamkan selama 24 jam, kemudian disaring dengan kain flanel. Filtrat etanol yang diperoleh disaring dengan corong Buchner, ampas selanjutnya diremaserasi sebanyak 2 kali dengan perlakuan yang sama pada saat proses maserasi. Setelah itu, filtrat yang diperoleh digabung dan dipekatkan dengan rotary evaporator hingga didapatkan ekstrak kental etanol.

\section{Penentuan aktivitas xanthine oxidase}

Aktivitas xanthine oxidase ditentukan dengan menambahkan $200 \mu$ l substrat (xanthine) $100 \mu \mathrm{g} / \mathrm{ml}$ ke dalam campuran $100 \mu \mathrm{l}$ xanthine oxidase $50 \mathrm{mU} / \mathrm{ml}$ dan $724 \mu \mathrm{l}$ dapar fosfat $\mathrm{pH}$ 7,5. Aktivitas xanthine oxidase ditentukan dengan mengamati kecepatan pembentukan asam urat dari xanthine dengan spektrofotometri pada panjang gelombang $(\lambda) 295 \mathrm{~nm}$ dari menit ke-0 sampai menit ke-3 pada suhu $25^{\circ} \mathrm{C}$. Data yang diperoleh adalah berupa rate $\left(\Delta \mathrm{A}_{295} /\right.$ menit $)$ (Anonim, 1994).

\section{Penentuan penghambatan aktivitas xanthine oxidase}

Penghambatan aktivitas xanthine oxidase ditentukan seperti pada point 4 di atas. Bedanya, pada tahap ini dilakukan penambahan $200 \mu \mathrm{l}$ allopurinol pada konsentrasi $10 \mu \mathrm{g} / \mathrm{ml}$ sampai $100 \mu \mathrm{g} / \mathrm{ml}$ kedalam campuran dapar fosfat, xanthine dan xanthine oxidase. Dengan cara yang sama, ditentukan pula penghambatan aktivitas xanthine oxidase oleh $200 \mu \mathrm{l}$ larutan uji (dilakukan orientasi menggunakan konsentrasi $10 \mu \mathrm{g} / \mathrm{ml}$ sampai $100 \mu \mathrm{g} / \mathrm{ml}$ ).

\section{Analisis data}

Data yang diperoleh berupa hasil pengukuran serapan secara spektrofotometri UV yaitu $\Delta \mathrm{A} /$ menit. Data $\Delta \mathrm{A} /$ menit ini digunakan untuk menghitung aktivitas xanthine oxidase dengan rumus (Anonim, 1994):

Aktivitas (unit/ml enzim) $=\frac{(\text { rate } \times 1,024)}{(12,2 \times 0,100)}$

Keterangan:

$1,024=$ volume total campuran

$12,2=$ koefisien ekstingsi asam urat $(\mathrm{mM})$

$0,100=$ volume enzim yang digunakan $(\mathrm{ml})$

Rate $=\Delta$ absorbansi $/$ menit

Data yang diperoleh (unit/ ml enzim) digunakan untuk menghitung aktivitas dalam unit/mg solid.

Aktivitas (unit $/ \mathrm{mg}$ solid) $=\frac{\text { (unit } / \mathrm{ml} \text { enzim })}{(0,0062 \mathrm{mgsolid} / \mathrm{ml})}$

Keterangan : 0,0062 $=$ mg solid $x$ anthine oxidase yang digunakan (mg solid/ml)

Data digunakan untuk menghitung persentase penghambatan xanthine oxidase dengan rumus:

$\%$ inhibisi $=\frac{\text { aktivitas tanpa bahan uji }- \text { aktivitas bahan uji }}{\text { aktivitas tanpa bahan uji }} \times 100 \%$

Nilai IC $_{50}$ (konsentrasi inhibitor yang menghasilkan penghambatan aktivitas xanthine oxidase sebesar (50\%) dapat ditentukan dengan analisis regresi linier antara konsentrasi senyawa uji terhadap persentase penghambatan aktivitas xanthine oxsidase, kemudian dilanjutkan dengan 
uji statistik dengan uji t dengan taraf kepercayaan 95\%.

\section{HASIL DAN PEMBAHASAN}

\section{Determinasi Tanaman}

Untuk menghindari terjadinya kesalahan sampel, langkah awal yang harus dilakukan adalah determinasi tanaman sarang semut yang digunakan. Determiasi tanaman pada penelitian ini dilakukan di Bagian Biologi Farmasi Fakultas Farmasi UGM Yogyakarta. Hasilnya adalah bahwa tanaman yang digunakan benar-benar sarang semut (Myrmecodia tuberosa (non Jack) Bl.).

\section{Pembuatan Ekstrak Etanol Sarang Semut}

Pada penelitian ini metode penyarian yang dipilih adalah maserasi karena cara pengerjaan dan peralatan yang digunakan sederhana, dan mudah diusahakan. Sedangkan etanol (96\%) dipilih sebagai larutan penyari karena sifatnya yang semi polar sehingga flavonoid yang bersifat semi polar maupun polar dapat yang terdapat dalam sarang semut bisa tersari atau terekstraksi. Kelebihan etanol sebagai penyari antara lain: lebih efektif, kapang dan kuman sulit tumbuh dalam etanol $20 \%$ ke atas, relatif tidak toksik, netral, etanol dapat bercampur dengan air pada segala perbandingan, dan panas yang diperlukan untuk pemekatan sedikit (Anonim, 1986). Tetapi sebelum penyarian dengan etanol dimulai, dilakukan pengawalemakan terhadap serbuk sarang semut menggunakan petroleum eter untuk menghilangkan lipid sehingga flavonoid lebih mudah terekstraksi dengan pelarut etanol.

Setelah dilakukan penyarian selama tiga hari, sari yang diperoleh selanjutnya dipekatkan menggunakan rotary evaporator sampai didapatkan ekstrak kental. Dari serbuk sarang semut sebanyak 100 gram diperoleh ekstrak kental sebanyak 6,23 gram dengan rendemen $6,23 \%$.

\section{Penentuan Aktivitas Xanthine Oxidase}

Aktivitas xanthine oxidase ditentukan menggunakan spektrofotometri dengan mengamati kecepatan pembentukan asam urat pada panjang gelombang $(\lambda) 295 \mathrm{~nm}$. Xanthine mempunyai serapan disekitar $\lambda 260 \mathrm{~nm}$ (Nagao dkk, 1999). Menurut Van Hoorn dkk (2002) selama 6 menit kinetika reaksi linier. Kecepatan pembentukan asam urat pada penelitian ini linier sampai menit ke-3. Kurva mulai landai pada menit ke-4, sehingga untuk penentuan selanjutnya hanya dilakukan pada menit ke-0 sampai ke-3.

\section{Penentuan Penghambatan Aktivitas Xanthine Oxidase}

Penentuan penghambatan aktivitas xanthine oxidase dimulai dengan melakukan orientasi untuk menentukan konsentrasi larutan allopurinol sebagai pembanding dan larutan uji ekstrak etanol sarang semut. Berdasarkan orientasi yang telah dilakukan, digunakan larutan allopurinol dengan konsentrasi 2,5 $\mu \mathrm{g} / \mathrm{ml}$; $5,0 \mu \mathrm{g} / \mathrm{ml}$ dan $7,5 \mu \mathrm{g} / \mathrm{ml}$. Sedangkan larutan ekstrak etanol dengan konsentrasi $90 \mu \mathrm{g} / \mathrm{ml}$, $110 \mu \mathrm{g} / \mathrm{ml}$, dan $130 \mu \mathrm{g} / \mathrm{ml}$. Setelah melalui beberapa replikasi, hasil uji penghambatan aktivitas xanthine oxidase dengan atau tanpa bahan uji dapat dilihat pada Tabel I.

\begin{tabular}{lcl} 
Tabel I. & $\begin{array}{c}\text { Hasil uji penghambatan aktivitas } \\
\text { Xanthine Oxidase }\end{array}$ \\
\hline Bahan Uji & $\begin{array}{c}\text { Konsentrasi } \\
\text { ( } \boldsymbol{\mu g} / \mathbf{m l})\end{array}$ & $\begin{array}{c}\text { Aktivitas } \pm \text { SD } \\
\text { (unit/mg solid) }\end{array}$ \\
\hline Tanpa & 0 & $0,4964 \pm 0,0313$ \\
& 2,5 & $0,2844 \pm 0,0136$ \\
Allopurinol & 5,0 & $0,1624 \pm 0$ \\
& 7,5 & $0,1173 \pm 0,0156$ \\
Ekstrak & 90 & $0,3384 \pm 0,0271$ \\
etanol & 110 & $0,2618 \pm 0,0078$ \\
& 130 & $0,1760 \pm 0$ \\
\hline
\end{tabular}

Berdasarkan data-data pada kolom “aktivitas" pada Tabel I diketahui adanya penurunan aktivitas xanthine oxidase karena penambahan larutan uji (sampel). Profil penurunan aktivitas xanthine oxidase karena allopurinol dapat dilihat pada Gambar 3 dan penambahan larutan uji sebagaimana dilihat pada Gambar 4.

Berdasarkan data-data pada Tabel I, dihitung persentase penghambatan (\% inhibisi) untuk tiap-tiap bahan uji dan diperoleh data-data sebagaimana tertera pada Tabel II. Nilai-nilai inhibisi pada Tabel II menunjukkan bahwa 
semakin besar konsentrasi bahan uji, semakin besar pula persentase penghambatannya sehingga aktivitas xanthine oxidase semakin menurun.

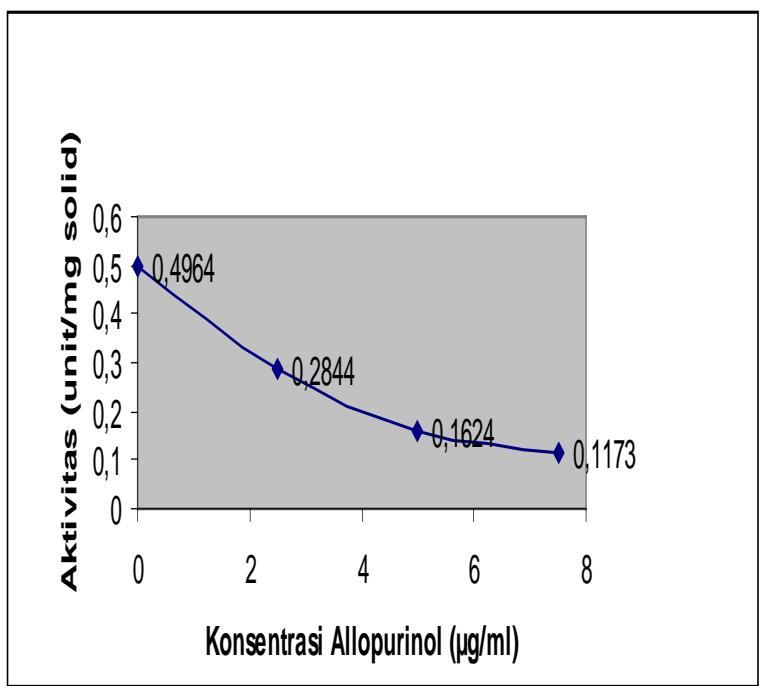

Gambar 3. Grafik hubungan antara konsentrasi allopurinol terhadap aktivitas Xanthine Oxidase

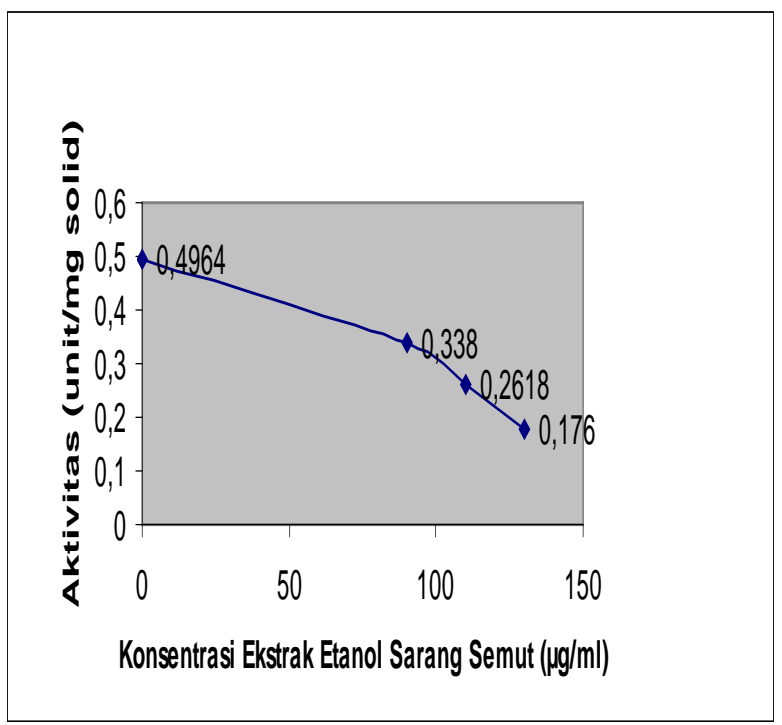

Gambar 4. Grafik hubungan antara konsentrasi ekstrak etanol sarang Semut dengan aktivitas Xanthine Oxidase

Berdasarkan data-data pada Tabel II, dihitung persentase penghambatan (\% inhibisi) untuk tiap-tiap bahan uji dan diperoleh data-data sebagaimana tertera pada Tabel III. Nilai-nilai inhibisi pada Tabel III menunjukkan bahwa semakin besar konsentrasi bahan uji, semakin besar pula persentase penghambatannya sehingga aktivitas xanthine oxidase semakin menurun.
Tabel II. Nilai inhibisi dari ekstrak etanol sarang semut dan allopurinol

\begin{tabular}{ccc}
\hline Bahan uji & $\begin{array}{c}\text { Konsentrasi } \\
(\boldsymbol{\mu g} / \mathbf{m l})\end{array}$ & Inhibisi (\%) \\
\hline Tanpa bahan uji & - & 0 \\
& & 45,45 \\
& 2,5 & 42,71 \\
& & 39,99 \\
Allopurinol & 5,0 & 67,28 \\
& & 67,28 \\
& & 67,28 \\
& 7,5 & 72,72 \\
& & 78,18 \\
& & 78,18 \\
& 90 & 31,83 \\
Ekstrak etanol & & 37,29 \\
sarang semut & \multirow{2}{*}{110} & 26,37 \\
& & 45,45 \\
& & 48,17 \\
& \multirow{2}{*}{130} & 48,17 \\
& & 64,54 \\
& & 64,54 \\
\end{tabular}

Berdasarkan data pada Tabel II dibuat persamaan regresi linier untuk tiap-tiap bahan uji untuk menentukan nilai $\mathrm{IC}_{50}$. Harga $\mathrm{IC}_{50}$ menunjukkan besarnya konsentrasi bahan uji yang dapat menghambat aktivitas xanthine oxidase sebesar $50 \%$. Nilai $\mathrm{IC}_{50}$ diperoleh dari persamaan regresi linier antara konsentrasi bahan uji (sumbu $\mathrm{x}$ ) dengan persentase penghambatan aktivitas xanthine oxidase oleh bahan uji sumbu y). Dari Tabel III diperoleh bahwa nilai IC $_{50}$ ekstrak etanol sarang semut adalah 35 kali lebih besar dibandingkan dengan nilai IC $_{50}$ allopurinol yang menunjukkan bahwa daya hambat aktivitas xanthine oxidase oleh ekstrak etanol sarang semut lebih rendah dibandingkan dengan allopurinol.

Tabel III. Nilai IC I0 $_{50}$ allopurinol dan ekstrak etanol

\begin{tabular}{cccl}
\hline Bahan Uji & $\begin{array}{c}\mathbf{I C}_{\mathbf{5 0}} \\
(\boldsymbol{\mu g} / \mathbf{m l})\end{array}$ & $\begin{array}{c}\text { Rata- } \\
\text { rata IC } \\
(\boldsymbol{\mu g} / \mathbf{m l})\end{array}$ & $\begin{array}{c}\text { Nilai SD, } \\
\mathbf{C V}, \text { Dan } \\
\mathbf{L E}\end{array}$ \\
\hline & 2,83 & & $\mathrm{SD}=0,31$ \\
Allopurinol & 3,21 & 3,16 & $\begin{array}{l}\mathrm{CV}= \\
\end{array}$ \\
& 3,45 & & $9,81 \%$ \\
& & & $\mathrm{LE}=0,77$ \\
Ekstrak & 113,30 & & $\mathrm{SD}=2,06$ \\
etanol & 110,04 & 112,40 & $\mathrm{CV}=$ \\
& 113,85 & & $\mathrm{LE}=5,12$ \\
\hline
\end{tabular}


Nilai IC $_{50}$ ekstrak etanol sarang semut yang besar $(112,40 \mu \mathrm{g} / \mathrm{ml})$ mungkin disebabkan oleh ekstrak yang mengandung glikosida flavonoid, tanin, dan polifenol sehingga perlu dilakukan hidrolisis terlebih dahulu. Berdasarkan data-data aktivitas xanthine oxidase (Tabel I), besar inhibisi (Tabel II), dan nilai IC $_{50}$ (Tabel III), dapat dikatakan bahwa ekstrak etanol sarang semut mampu menghambat aktivitas xanthine oxidase terkait dengan adanya senyawa flavonoid yang terkandung didalamnya (hasil uji pendahuluan adanya flavonoid dan pemeriksaan Kromatografi Lapis Tipis). Penurunan aktivitas xanthine oxidase terjadi jika larutan uji mengandung flavonoid terutama yang mempunyai gugus 5,7-dihidroksi pada cincin A (misalnya flavon) yang mirip dengan the six membered ring of xanthine (dalam bentuk enol) (Van Hoorn dkk., 2002). Jika dibandingkan dengan allopurinol, penurunan aktivitas xanthine oxidase yang terjadi karena allopurinol merupakan inhibitor allosterik xanthine oxidase (Lam dkk., 2006) yang mereduksi gugus reaktif oksidasi-reduksi xanthine oxidase (Massey dkk., 1970).

Kemudian nilai $\mathrm{IC}_{50}$ yang diperoleh dianalisis dengan uji statistik yaitu menggunakan uji t untuk mengetahui apakah ada perbedaan antara dua kelompok yang dibandingkan allopurinol dengan ekstrak etanol sarang semut. Dari hasil uji diketahui bahwa ada perbedaan antara dua kelompok dengan nilai signifikansi $0,000<0,05$.

\section{KESIMPULAN}

Ekstrak etanol sarang semut mempunyai kemampuan menghambat aktivitas xanthine oxidase. Ekstrak etanol sarang semut menghambat aktivitas xanthine oxidase dengan nilai $\quad \mathrm{IC}_{50} 112,40 \mu \mathrm{g} / \mathrm{ml}$, sedangkan $\mathrm{IC}_{50}$ allopurinol adalah 3,16 $\mu \mathrm{g} / \mathrm{ml}$. Kemampuan penghambatan aktivitas xanthine oxidase oleh ekstrak etanol sarang semut lebih kecil dibandingkan dengan allopurinol.

\section{DAFTAR PUSTAKA}

Anonim. 1986. Sediaan Galenik. 10-11; 16. Departemen Kesehatan Republik Indonesia. Jakarta.
Ansel, H.C. 1989. Pengantar Bentuk Sediaan Farmasi. Edisi IV. 96-147. UI Press. Jakarta.

Anonim. 1994. Enzymatic Assay of Xanthine Oxidase (EC 1.1.3.22), Sigma Aldrich.

Cos, P., Ying, ., Calomme,M., J.P. Cimanga, K., Van Poel, B., Pieters, L., Vlietinck, A.J., dan Vanden Berghe, D., 1998. Structure Activity and Classification of Flavonoids as Inhibitor Xanthine Oxidase and Superoxide Scavengers, J. Nat. Prod 61 : 71-76.

Dipiro, J.T, R.L. Talbert, G.C. Yee, G.R. Matzke, B.G. Wells \& L.M. Posey. 2005. Pharmacotherapy; A Pathophysiologic Approach, 6th edition, The McGraw-Hill Companies, Inc., New York.

Lam, L.H., Sakaguchi, K., Ukeda, H., and Sawamura, M. 2006. Flow Injection Determination of Xanthine Oxidase Inhibitory Activity and Its Application to Food Samples, Anal. Sci., (22): 105-109.

Massey, V., Komai, H., dan Palmer, G. 1970. On the Mechanism of Inactivation of Xanthine Oxidase by Allopurinol and Other Pyrazolo(3,4-d)pyrimidine, J., Biol. Chem., 245(11): 2837-2844.

Markham, K.R. 1988. Cara Mengidentifikasi Flavonoid, diterjemahkan oleh Kosasih Padmawinata, 2-5, 10, 15-20, ITB Press, Bandung.

Nagao, A., Seki, M., and Kobayashy, H. 1999. Inhibition of xanthine oxidase by flavonoids, Biosci. Biotechnol. Biochem., 63 (10): 1787.

Price, S. A., dan Wilson, L. M. 2005. Patofisiologi Konsep Klinis Proses ProsesPenyakit, diterjemahkan oleh Dharma, Adji, Edisi 6 volume 1, 437-446, Penerbit buku Kedokteran EGC, Jakarta.

Robinson, T. $1995 . \quad$ Kandungan Organik Tumbuhan Tinggi, Edisi VI, Hal 57; 73, diterjemahkan oleh Kosasih Padmawinata, ITB, Bandung. 
Subroto, M. A., dan Saputro, H. 2006. Gempur Penyakit dengan Sarang Semut, 13,1517,21,27,-32, Penebar Swadaya, Jakarta.

Subroto, M.A., Fanny, Partomuan Simanjuntak, 2010. Isolasi Senyawa Aktif dari Senyawa Hipokotil Sarang Semut (Myrmecodia pendens Merr dan Perry) sebagai Penghambat Xantin Oxidase. Bogor: LIPI.Vol.8, No.1.

Walker, R. dan Edward, C. 2003. Clinical Pharmacy And Therapeutics, Edisi III, Churchill Livingstone, USA
Wibowo, S. 2006. Asam Urat, http://suryo_wibowo.blogspot.com. Diakses pada tanggal 2 April 2012.

Van Hoorn, D.E.C., Nijveldt, R.J., van Leeuwen, P.A.M., Hofman, Z., M'Rabet., De Bont, D.B.A., and van Norren K. 2002. Accurate prediction of xanthine oxidase inhibition based on the structure of flavonoids, Eur. J. Pharmacol., 451:111118. 